\title{
Evaluation of the Effect of Short-Term Cadmium Exposure on Brackish Water Shrimp-Palaemonetes africanus
}

\author{
${ }^{1}$ JOEL O. F., ${ }^{2}$ AMAJUOYI, C.A \\ ${ }^{1}$ Department of Petroleum and Gas Engineering, Faculty of Engineering, \\ University of Port Harcourt, Nigeria.Ogbonna.Joel@yahoo.com;08052276568, 08037099211. \\ ${ }^{2}$ Pollution Control and Environmental Management Limited, Port Harcourt, Nigeria.
}

\begin{abstract}
This study evaluated the effect of short-term cadmium exposure on brackish water shrimpPalaemonetes africanus. Tests were carried out by exposing the shrimps to the test solutions containing various concentrations of the cadmium $(0,0.1,1.0,4.0,6.0,8.0,10.0$, and 100.0$) \mathrm{mg} / 1$ using the semi-static agitation test procedure. Mortality was recorded at 2, 4, 6, 8, 10,12, 14 and 16 hours exposure periods. Test results indicated that the brackish water juvenile shrimp, Palaemonetes africanus were sensitive to the cadmium solution especially at concentration above $4.0 \mathrm{mg} / 1$. Though no death was recorded after $16 \mathrm{hrs}$ for $0.1 \mathrm{mg} / 1,1.0 \mathrm{mg} / 1$ and $4.0 \mathrm{mg} / 1$ respectively, however, for $6 \mathrm{mg} / 1,60 \%$ mortality was recorded after $4 \mathrm{hrs}$ and $100 \%$ after $8 \mathrm{hrs}$, for $8 \mathrm{mg} / 1,20 \%$ mortality was recorded after $2 \mathrm{hrs}, 60 \%$ after $4 \mathrm{hrs}, 80 \%$ after $6 \mathrm{hrs}$ and $100 \%$ mortality after $8 \mathrm{hrs}$ respectively, for $10 \mathrm{mg} / \mathrm{l}, 40 \%$ mortality was recorded after $2 \mathrm{hrs}$ and $100 \%$ after $4 \mathrm{hrs}$ and $100 \%$ mortality was recorded for $100 \mathrm{mg} / 1$ after $2 \mathrm{hrs}$. The $\mathrm{LC}_{50}$ value calculated using Arithmetic Method of Karber was $5.0 \mathrm{mg} / \mathrm{l}$. It is therefore evident that the effects of acute toxicity of cadmium are concentration-related; the greater the concentration, the greater the effect. @ JASEM
\end{abstract}

Cadmium is highly toxic to wildlife; it is cancercausing and teratogenic and potentially mutationcausing, with severe sub-lethal and lethal effects at low environmental concentrations (Eisler 1985a). It is associated with increased mortality, and it affects respiratory functions, enzyme levels, muscle contractions, growth reduction, and reproduction. It bio-accumulates at all trophic levels, accumulating in the livers and kidneys of fish (Sindayigaya, et al. 1994; Sadiq, 1992). Crustaceans appear to be more sensitive to cadmium than fish and mollusks (Sadiq 1992). Metal accumulation in tissues of fish is dependent upon exposure dose and time as well as other factors such as temperature, age of fish, interaction with other metals, water chemistry and metabolic activity of the fish (Pagenkopf 1983, Heath 1987, Goyer 1991).

Studies revealed effects of the combination of cadmium and zinc in an aquatic environments (Kargin 1996). Zinc has an antagonistic and protective action in the uptake and toxic effects of cadmium, probably because of $\mathrm{Zn}$-induced synthesis of metallothionein that detoxifies cadmium by firmly binding this metal (Hemelmad, et al., 1987). Similar effects have been observed in the interaction of heavy metals such as selenium and mercury (Lucu and Skreblin, 1981).

Generally, the effect of heavy metals on aquatic organisms ranges from slight reduction in growth rate to death. Severe imbalances in concentration can lead to death, while marginal imbalances may cause poor health and retarded growth. Concentrations determined to be lethal in the laboratory tests occur commonly in nature (Abowei and Sikoki, 2005).

* Corresponding author: Joel O. F.
Research has shown that metal accumulation is more rapid than metal elimination, probably due to the presence of metal binding proteins in tissues and this has contributed to their deleterious effect. This is because several factors influence the elimination of metals from the tissues of aquatic animals. These include time, temperature, interacting agents, age of fish, metabolic activity of animals and biological half lives of metals (Larson et al., 1985; Heath, 1987, Rao et al., 1988, Douben, 1989, Woo et al., 1993, Kargm 1996, Nielsen and Andersen 1996). Elimination routes of metals from fish are generally through gill, bile, urine, skin, and via mucus (Varanasi and Markey 1978, Heath 1987).

The objective of this work is to determine the potential acute toxicological effect of different cadmium concentrations on brackish water shrimpPalaemonetes africanus. This will help to determine the concentration-time effect and $\mathrm{LC}_{50}$ value as applicable.

\section{MATERIALS AND METHODS} Semi- static Bioassay Techniques:

Acute toxicity tests were carried out with aquatic organisms by exposing them (test organisms) to test solutions containing various concentrations of the test sample, using the semi-static agitation test procedure as recommended by Department of Petroleum Resources (DPR, 2002).

Sampling Test Organisms: Brackish water juvenile shrimp, Palaemonetes africanus were collected from the brackish water at Eagle Island Waterside, Port Harcourt, Nigeria. Juvenile shrimps were collected 
with the aid of sieves of appropriate mesh size during spring tide. They were transferred into $10 \mathrm{~L}$ coolers containing the habitat water (APHA, 1998).

Table 1: Average Weight of Test Organisms

\begin{tabular}{llll}
\hline $\mathrm{S} / \mathrm{N}$ & Name of Organism & $\begin{array}{l}\text { Type of } \\
\text { Habitat }\end{array}$ & $\begin{array}{l}\text { Weight of } \\
\text { Organism }\end{array}$ \\
\hline 1. & $\begin{array}{l}\text { Palaemonetes } \\
\text { africanus }\end{array}$ & $\begin{array}{l}\text { Brackish } \\
\text { water }\end{array}$ & $90 \pm 5 \mathrm{mg}$ \\
\hline
\end{tabular}

Table 2: Average Length of Test Organisms

\begin{tabular}{llll}
\hline $\mathrm{S} / \mathrm{N}$ & Name of Organism & $\begin{array}{l}\text { Type of } \\
\text { Habitat }\end{array}$ & $\begin{array}{l}\text { Weight of } \\
\text { Organism }\end{array}$ \\
\hline 1. & $\begin{array}{l}\text { Palaemonetes } \\
\text { africanus }\end{array}$ & $\begin{array}{l}\text { Brackish } \\
\text { water }\end{array}$ & $2.5 \pm 0.5 \mathrm{~cm}$ \\
\hline
\end{tabular}

Acclimatization Procedure: All test organisms were first acclimatized for ten days at room temperature 28 $\pm 2^{\circ} \mathrm{C}$. They were acclimatized in dark glass tanks in which air (oxygen) was continuously bubbled into, through an aerator. They were also fed with fish feed obtained from the Institute of Fisheries at Aluu near University of Port Harcourt during the period of acclimatization. The water in the acclimatization units was replaced with the fresh water from the organism's habitat daily. There was controlled lighting system, as 12hours of light and 12hours of darkness was employed (DPR, 2002).

Selection of Test Organism: Twenty test organisms of fairly equal size were randomly caught with a hand net from acclimatization tanks and carefully transferred into the test vessel. The organisms were not touched with hand during the selection so as to avoid stress due to handling. Only healthy and active test organisms were selected.

Choice of Bioassay Tanks: The bioassay containers were made of dark glass of $30 \mathrm{~cm} \times 21 \mathrm{~cm} \times 25 \mathrm{~cm}$ dimension. These were constructed with removable stands for easy cleaning and movement. The tanks were washed with detergent, rinsed with distilled water and dried overnight to avoid contamination.

Range Finding Test: Range Finding Test was carried out to establish a preliminary working range by obtaining the least concentration that gives no effect and the minimum concentration that gives $100 \%$ death. Test design incorporated multiple, widely spaced concentrations with single replicates. Exposure times were $4 \mathrm{hr} ., 8 \mathrm{hr} ., 24 \mathrm{hr} .$, and $48 \mathrm{hr}$.
Source of Cadmium Standard: Cadmium standard was gotten from Buck Scientific, PURO-GRAPHIC ${ }^{\text {tm }}$ Standards, East Norwalk, CT 06855, Canada.

Test Medium: Four different concentrations of the test sample $(0.1 \mathrm{mg} / 1,1.0 \mathrm{mg} / 1,4.0 \mathrm{mg} / 1,6.0 \mathrm{mg} / 1,8.0 \mathrm{mg} / 1$, $10.0 \mathrm{mg} / \mathrm{l}$, and $100.0 \mathrm{mg} / \mathrm{l})$ were prepared using habitat water of the particular organism as diluent. This followed after a preliminary range finding test. The corresponding aliquots were added to the test vessels constructed of glass. The aliquots were first stirred for $5 \mathrm{mins}$ and subsequently at 4 hourly intervals.

Serial Dilutions Used: For $100 \mathrm{mg} / 1$, about $100 \mathrm{ml}$ aliquot of the cadmium standard concentration was measured and diluted to 1 litre with the brackish water (diluent). For $10 \mathrm{mg} / 1,8 \mathrm{mg} / 1,6 \mathrm{mg} / 1,4 \mathrm{mg} / 1$ and $1 \mathrm{mg} / \mathrm{l}$, $0.1 \mathrm{mg} / \mathrm{l}$ ) concentrations, about $10 \mathrm{ml}, 8 \mathrm{ml}, 6 \mathrm{ml}, 4 \mathrm{ml}$, $1 \mathrm{ml}$ and $0.1 \mathrm{ml}$ aliquots of the cadmium standard concentrations respectively were diluted to 1 litre with the diluent.

Twenty test organisms were used in each concentration. Healthy, active test organisms were carefully introduced into bioassay vessels representing different concentrations. Three hundred and sixty test organisms ( $P$. africanus) consisting of twenty organisms per concentration made up of six concentration levels. Controls containing dilution water, and twenty test organisms were prepared without the toxicant and this served as the control. Each of the test concentrations was labeled appropriately. After each day, the media were replaced with fresh one. Dead organisms were also removed at the end of each exposure period. This was done to avoid contamination of live organisms by bacteria from dead decaying organisms. Mortality was recorded at 2, 4, 6, 8, 10,12, 14 and 16 hour exposure periods (Finney, 1978 and Sprague, 1973).

$L C_{50}$ Determination: The number of dead fishes per group was recorded against the time of their death in a tabular form as specified by Sprague (1972). The data obtained was used to calculate the median lethal concentration $\left(\mathrm{LC}_{50}\right)$ of the Cadmium solution on $P$. africanus using Arithmetic Method of Karber

\footnotetext{
* Corresponding author: Joel O. F.
} 
PHYSICO-CHEMICAL ANALYSIS:

- pH, Temperature, Conductivity, TDS and Dissolved Oxygen:

These chemical properties were determined electrometrically with a multi- parameter data logger (Hanna model HI991300).

\section{- Salinity:}

Salinity was determined titrimetrically in accordance with APHA 2520A.

\section{- Alkalinity:}

Alkalinity was determined in accordance with ASTM D 1067B. This method involved titration of $100 \mathrm{ml}$ of sample against $0.01 \mathrm{M} \mathrm{HCl}$ with the addition of $2-3$ drops of phenolphthalein indicator.

\section{- Hardness:}

Total hardness in water was determined in accordance with APHA 2340C. This method involved the addition of a standard EDTA solution to $50 \mathrm{ml}$ of the sample in $250 \mathrm{ml}$ conical flask. The mixture was stirred continuously until a reddish tinge disappeared and there was a color change to sky blue.

\section{RESULTS AND DISCUSSION}

Table 3: Some Physicochemical Characteristics of the Brackish Water

\begin{tabular}{ll}
\hline Parameter & Test Result \\
\hline $\mathrm{pH}$ & 6.61 \\
Temperature $\left({ }^{\circ} \mathrm{C}\right)$ & 26.5 \\
Electrical Conductivity $\left(\mu \mathrm{Scm}^{-1}\right)$ & 1670 \\
Total Dissolved Solids $(\mathrm{mg} / \mathrm{l})$ & 843 \\
Dissolved Oxygen $(\mathrm{mg} / \mathrm{l})$ & 7.97 \\
Total Hardness $(\mathrm{mg} / \mathrm{l})$ & 740 \\
Alkalinity $(\mathrm{mg} / \mathrm{l})$ & 60 \\
\hline
\end{tabular}

Table 4: Concentration-Time Effect of Cadmium on Brackish water Shrimp (Palaemonetes africanus)

\begin{tabular}{llllllll}
\hline & \multicolumn{7}{c}{$\%$ Mortality } \\
\hline Concentrations (mg/l) & 0.1 & 1.0 & 4.0 & 6.0 & 8.0 & 10.0 & 100.0 \\
4Hours & 0 & 0 & 0 & 0 & 20 & 40 & 100 \\
6 Hours & 0 & 0 & 0 & 60 & 60 & 100 & 100 \\
8 Hours & 0 & 0 & 0 & 60 & 80 & 100 & 100 \\
10 Hours & 0 & 0 & 0 & 100 & 100 & 100 & 100 \\
12 Hours & 0 & 0 & 0 & 100 & 100 & 100 & 100 \\
14 Hours & 0 & 0 & 0 & 100 & 100 & 100 & 100 \\
16 Hours & 0 & 0 & 0 & 100 & 100 & 100 & 100 \\
\hline
\end{tabular}

Table 5: $\mathrm{LC}_{50}$ Determination Based on Arithmetic Method of Karber.

\begin{tabular}{lccccc}
\hline $\begin{array}{l}\text { Concentration } \\
(\mathrm{mg} / \mathrm{l})\end{array}$ & $\begin{array}{l}\text { Concentration } \\
\text { Difference }\end{array}$ & $\begin{array}{l}\text { Number } \\
\text { Alive }\end{array}$ & $\begin{array}{l}\text { Number } \\
\text { Dead }\end{array}$ & $\begin{array}{l}\text { Mean Death } \\
\text { Mean Death } \\
\text { Dose Difference }\end{array}$ \\
\hline 0 (Control) & - & 20 & 0 & - & 0 \\
0.1 & 0.1 & 20 & 0 & 0 & 0 \\
1.0 & 0.9 & 20 & 0 & 0 & 0 \\
4.0 & 3.0 & 0 & 0 & 0 & 0 \\
6.0 & 2.0 & 0 & 20 & 10 & 20 \\
8.0 & 2.0 & 0 & 20 & 20 & 40 \\
10.0 & 2.0 & 0 & 20 & 20 & 40 \\
100.0 & 90.0 & 0 & 20 & 20 & 1800 \\
& & & & & $\sum=1900$ \\
\hline
\end{tabular}

$$
\begin{aligned}
& \mathrm{LC}_{50}=\mathrm{LC}_{100}-\sum \text { Conc. } \text { Diff } \times \text { Mean Death } \\
& \text { No. of org. per group } \\
& =100-\frac{1900}{20} \\
& \mathrm{LC}_{50}=100-95=5.0(\mathrm{mg} / \mathrm{l}) .
\end{aligned}
$$

Table-3 presents some physico-chemical characteristics of the brackish water. As indicated the $\mathrm{pH}$ was 6.61, Temperature $\left(26.5^{\circ} \mathrm{C}\right)$, Electrical conductivity $\left(1670 \mu \mathrm{Scm}^{-1}\right)$, Total dissolved solids $(843 \mathrm{mg} / \mathrm{l})$, Dissolved oxygen $(7.97 \mathrm{mg} / \mathrm{l})$, Total hardness $(740 \mathrm{mg} / \mathrm{l})$ and Alkalinity $(60.0 \mathrm{mg} / \mathrm{l})$.

The dose - time effect of the different concentrations of Cadmium on the brackish water shrimp -

* Corresponding author: Joel O. F.
Palaemonetes africanus is presented in table 4. Test results indicated that at $0.1 \mathrm{mg} / \mathrm{l}$ and $1.0 \mathrm{mg} / 1$ and $4.0 \mathrm{mg} / 1$ concentrations respectively, there was no death of the shrimps that is, mortality rate was $0 \%$. For $6 \mathrm{mg} / 1$ after $2 \mathrm{hrs}$, mortality rate was $0 \%$, after $4 \mathrm{hrs}$ and $6 \mathrm{hrs}$ respectively; mortality rate was $100 \%$ after 8 hrs. For $8 \mathrm{mg} / 1,20 \%$ mortality rate was noticed after $2 \mathrm{hrs}, 60 \%$ mortality rate after $4 \mathrm{hrs}$ and $80 \%$ 
after 6 hrs and $100 \%$ mortality after $8 \mathrm{hrs}$. It was observed that while $40 \%$ mortality rate was recorded after $2 \mathrm{hrs}$ and $100 \%$ after $4 \mathrm{hrs}$ for $10 \mathrm{mg} / \mathrm{l}$ concentration, $100 \%$ was observed after $2 \mathrm{hrs}$ for $100 \mathrm{mg} / \mathrm{l}$. Research has shown that chemicals at a given concentration which would have been harmless as a stand alone may cause deleterious effects by interacting in the general milieu of contaminated waters (Joel, et al., 2009). Therefore, the lower concentrations as seen in this test that resulted to no death of the test organisms may have toxic effect if there are other contaminants in the aquatic habitat.

As effluent from many sources enters natural waters, the negative impact on the aquatic ecosystem is due to a mixture of metals, rather than individual component metals. When metal mixtures are discharged into the environment they may show a number of effects, which are synergistic, antagonistic or additive in nature (Grobler et al., 1989).

The $\mathrm{LC}_{50}$ value calculated using Arithmetic Method of Karber was $5.0 \mathrm{mg} / \mathrm{l}$ (Table 5). From the standard toxicity rating of chemicals by Sprague, the test solution was slightly toxic (Sprague, 1973).

Conclusion: The semi - static bioassay revealed that the higher the concentration of the cadmium solution, the higher the $\%$ mortality rate. It is therefore evident that the effects of acute toxicity of cadmium are concentration-related; the greater the concentration, the greater the effect.

\section{REFERENCE}

Abowei, JFN and Sikoki, FD (2005). Water Pollution Management and Control, Doubletrust Publication Company, Port Harcourt, 87pp.

American Public Health Association (1998). Standard Methods for the Examination of Water and Wastewater $20^{\text {th }}$ Edition Edited by Andrew D. Greenberg et al.

Department of Petroleum Resources (2002). Environmental Guidelines \& Standards for the Petroleum Industry in Nigeria, pp 281-291.

Douben PET (1989). Metabolic rate and uptake and loss of cadmium from food by the fish Noemacheilus barbatulus L. (stone loach). Environ Pollut 59: 177-202.

* Corresponding author: Joel O. F.
Eisler, R (1985a). Cadmium hazards to fish, wildlife, and invertebrates: A Synoptic Review. US Fish Wildl. Ser. Biol. Rep. 85(1.2).

Finney, D J (1978). Statistical Methods in Biological Assay 3rd Edition. Charles Griffin, London.

Grobler EDU, Preez HH and VAN Vuren JHJ (1989). Toxic effects of zinc and iron on the routine oxygen consumption of Tilapia sparrmanii (Cichlidae). Comp. Biochem. Physiol. 94C (1) 207-214.

Goyer R A (1991). Toxic Effects of Metals in Casarett and Doull's Toxicology: Basic Science of Poisons 4th Edition 1033 pp. Pergamon Press, Oxford.

Heath AG (1987). Water Pollution and Fish Physiology CRC press 245 pp. Florida USA.

Hemelmad J, Kleinveld HA, De Ross AM, Holwerda DAD and Zandee D I (1987). Cadmium kinetics in freshwater clams. III. Effects of zinc on uptake and distribution of cadmium in Anadonta cygnea Arch Environ Contam Toxicol 16: 95101.

Joel, OF, Amajuoyi, CA and Dede, EB (2009). DoseTime Effect of Crude Oil and Hydro-test Effluent on Freshwater and Brackish Water Habitats. J. Appl. Sci. Environ. Manage. June, 2009, Vol. 13(2) 41-45.

Kargin F. (1996). Elimination of cadmium from Cdcontaminated Tilapia zilli in media containing EDTA and freshwater: changes in protein levels Bull Environ Contam. Toxicol 57: 211-216.

Larson A., Haux C and Sjöbeck M. (1985). Fish physiology and metal pollution: Results and experiences from laboratory and field studies, Ecotoxicol Environ Safety 9: 250-281.

Lucu C and Skreblin M. (1981). Evidence on the interaction of mercury and selenium in the shrimp Palaemon elegans. Mar Environ Res 5: 265-274.

Pagenkopf GK (1983). Gill surface interaction model for trace-metal toxicity to fishes: role of complexation, $\mathrm{pH}$ and water hardness. Environ Sci. Technol 17: 342-347. 
Rao, YP., Devi VU and Rao DGVP (1988). Influence of temperature on copper accumulation and depuration in a tropical cerithiid Cerithidea (cerithideopsill cingulat $a$ (Gmelin 1790). Water Air Soil Pollut. 37: 365-374.

Sadiq, M. (1992). Toxic metal chemistry in marine environments. Marcel Dekker. New York.

Sindayigaya, ERV, Cauwnbergh, Robberecht $\mathrm{H}$ and Deelstra, H (1994). Copper, zinc, manganese, iron, lead, cadmium, mercury, and arsenic in fish from Lake Tanganyika, Burundi. The Science of the Total Environment. 144:103-115.
Sprague JD (1972). The ABC's of pollutant bioassay using fish. A paper presented on environment monitory in Los Angeles, California, June 27 28 (ASTM).

Sprague JD (1973). The ABC of Pollution Assays using Fish, Biological Methods for Assessment of Water Quality, A.S.T.M. STP 528, pp 6-30.

Varanasi, U and Markey, D (1978). Uptake and release of lead and cadmium in skin and mucus of Coho salmon (Oncorhynchus kisutch). Comp. Biochem Physiol 60: 187-191.

Woo, PTK., Yoke, MS and Wong, MK (1993). The effects of short-term acute cadmium exposure on blue tilapia, Orcochromus aurues. Environ Biol. Fish 37: 67-74. 